\title{
THE ULTRASTRUCTURE OF EQUINE SYNOVIAL MEMBRANE
}

\author{
D. HORKÝ, F. TICHÝ* \\ Department of Histology and Embryology, Faculty of Medicine, Masaryk University, \\ Joštova 10, 66243 Brno, *Department of Anatomy and Histology, University of \\ Veterinary and Pharmaceutical Sciences, 61242 Brno
}

Received April 18, 1995

\begin{abstract}
Horký D., F. Tichý: The Ultrastructure of Equine Synovial Membrane. Acta vet. Brno, 1995, 64: 225-229.

The ultrastructure of synovial membrane was studied in two adult stallions of the English thorougbred horse. Samples were collected from 2 astragalar and 2 knee joints of stallions. The equine synovial membrane was composed of two cell types, $A$ and $B$, and the synovial matrix which extended into subsynovial tissue. Synoviocytes, located singly, were usually covered with synovial matrix; they were in contact with the joint cavity only occasionally. A-cells showed a structure generally similar to the mammalian cells of this type but they were flatter and had no cytoplasmic projections. The cytoplasm of B-cells was free of secretory granules and lacked fibrils passing through the plasma membrane. The synovial matrix of the surface layer showed numerous dense bodies. The occurrence of thick bundles of aperiodic filaments which were several $\mu \mathrm{m}$ long and $0.2-0.3 \mu \mathrm{m}$ thick was an unusual finding.
\end{abstract}

Ultrastructure, synovial matrix, synovial A cells, B cells, horse

The synovial membrane plays a key role in both physiology and pathology of synovial joints. This important finding was made fairly early and since then the structure of synovial membrane has been the subject of many investigations. First studies dealt with synovial membranes in experimental animals and later in humans. The present-day knowledge on its microscopic and submicroscopic structure as well as biochemical and immunochemical data on both normal and diseased joint are based on investigations carried out in a wide variety of mammalian and avian species by researchers in various biological fields (for review see Horký 1990, 1991). Observations of numerous authors have shown that the synovial membranes of all species so far studied are composed of two types of synovial cells, first classified by B arland et al. (1962), i. e., A or M (macrophage-like) and B or F (fibroblastlike) cells. A-cells are similar in structure to histiocytes. Their phagocytic capacity has been demonstrated in many mammalian species (Cutlip and Cheville 1973; Leach et al. 1988; Fabry 1989). B-cells, also found in most of the mammalian species, are characterised by well developed granular endoplasmic reticulum, an extensive Golgi apparatus and the presence of secretory granules. Occasionally these cells are also referred to as $\mathrm{S}$ (secretory) cells. In addition to Barland et al. (1962), they have been described by other authors, most recently by Meek et al. (1991), Worrall (1991), Levandon and S tein (1992) and Pasquali et al. (1991) in normal joints and in those affected by various pathological conditions.

In horses, information on synovial membrane is scarce. The first more detailed observations were presented by Johanson and Rejnö (1976) who compared synovial membranes of healthy joints with those of joints affected with intraarticular fractures of osteochondrosis dissecans. Equine synovial membrane is also mentioned in the work of Gangel (1984) and Hilbert et al. (1984) dealing with the properties of synovial fluid. These facts and our long-term involvement in studies on synovial membranes (Horký $1990,1991,1993$ ) have led to a decision to investigate this structure in the horse and thus contribute to information on this articular component in this mammalian species. 


\section{Materials and Methods}

Samples of synovial membrane were collected from 2 knee joint of two English thoroughbred stallions aged 2 years and from 2 astragalar joints of a stallion 8 years old. The samples of synovial membranes with attached subsynovial tissue were dissected, when immersed in fixation medium, into strips $(1 \times 1 \times 2-3 \mathrm{~mm})$ and immediately placed in $300 \mathrm{mmol} / \mathrm{L}$ glutaraldehyde in $0.1 \mathrm{M}$ phosphate buffer at $\mathrm{pH} 7.4$, first for $60 \mathrm{~min}$ and then, in a fresh solution, for further $180 \mathrm{~min}$. They were subsequently rinsed with 3 exchanges of $0.1 \mathrm{M}$ phosphate buffer at $\mathrm{pH}$ 7.4. This was followed by fixation with $40 \mathrm{mmol} / \mathrm{L} \mathrm{OsO}$ in phosphate buffer at $\mathrm{pH} 7.4$ for 15 and $45 \mathrm{~min}$. Dehydration, immersion and embedding in Durcupan ACM were carried out using standard methods, polymerisation took 3 days in the oven at $60^{\circ} \mathrm{C}$. Ultrathin sections were cut in an LKB ultramicrotome, stained with lead citrate according to Reynolds or by a method combining $1 \%$ uranyl acetate with lead citrate. They were examined and photographed in a Tesla BS 500 electron microscope. Semithin sections for light microscopy observations were stained with methylene blue and Azure II.

\section{Results}

\section{Ultrastructure of synoviocytes}

The equine synovial membrane was covered by two, occasionally three, layers of cells. These layers were covered by synovial matrix (Figs, 1,2,4). Deeper in the membrane, the matrix gradually became continuous with subsynovial tissue. Only small surface areas were not covered with the matrix and cells were in direct contact with the joint cavity (Fig. 3). The synovial membrane was not separated from subsynovial tissue by a basement membrane.

\section{A-cells}

In the equine synovial membrane, A-cells were found in lower numbers than B-type cells. They were most frequently located near the synovial surface, presenting as individual cells (Fig. 1). They differed in shape from the corresponding cells of other mammalian species; they were oval or elongated and measured about $8-10 \times 2-4 \mu \mathrm{m}$.

The nucleus was elongated or rod-like, with large, marked karyosomes situated at the nuclear envelope (Fig. 1). The nucleolus, if present, was of a reticular type. The zonula nucleum limitans was narrow, forming only a thin layer attached to the inner membrane of the nuclear envelope (Fig. 1).

The cytoplasm was present in a small amount as a narrow lining around the nucleus (Fig. 1). The granular endoplasmic reticulum presented as occasional short, flattened cisternae. The Golgi apparatus took up only a small region of cytoplasm and, if present in the section viewed, it showed its usual appearance. Mitochondria were small with only few cristae. Areas rich in cytoplasm contained smooth, electron transparent vesicles. Close to the cell membrane, there were pinocytotic vesicles. Lysosomes, centrioles or cytoplasmic filaments were not observed.

The cell membrane provided a smooth cover to almost all the surface. Occasionally, it extended into the surrounding matrix as short filopodia (Fig. 1).

B-cells

B-type cells were more frequent than A-cells and occurred as individual cells (Fig. 2) or in pairs (Fig. 5) either under or on the synovial surface (Fig. 3). In the latter case, they were located in folds of the membrane, were not covered by intercellular substance and were in direct contact with the joint cavity (Fig. 3).

The nucleus either was oval-shaped or had an irregular outline due to deep invaginations created by the nuclear envelope. Chromatin appearance was similar to that in A-cells.

The cytoplasm was present in larger amounts than in A-cells (Figs 2,3,5) with granular endoplasmic reticulum presenting as numerous narrow cisternae varying in length or as dilated vesicles up to $0.5 \mu \mathrm{m}$ in size (Figs 2,3 ) with finely granulated contents. Agranular 
endoplasmic reticulum was seen as numerous smooth, electron transparent vesicles, $0.2-0.3 \mu \mathrm{m}$ long. In addition to these structures, B cell cytoplasm, in areas close to the cell membrane, showed smooth vesicles, about $0.8 \mu \mathrm{m}$, with granular content which were considered transport vacuoles (Figs 2,4) and also smaller vesicles, $0.4-0.5 \mu \mathrm{m}$, filled either with dark homogeneous material or with structures resembling autophagic vacuoles or pseudomyelin structures (Fig. 2).

The Golgi apparatus was similar in appearance to that in A-cells. Its cisternae sequestered smooth vesicles which could be observed as a part of agranular endoplasmic reticulum in the cytoplasm.

Mitochondria showed the usual size and structure but occurred in larger numbers than mitochondria in A-cells.

Secretory granules in cytoplasm were a rare finding. However, they were frequently found close to cells in the synovial matrix (Fig. 1,2,3). They were bounded by a smooth membrane and contained either granular or dense homogeneous material.

Intracytoplasmic filaments were regularly observed near the nuclei of B-cells; they were either arranged in parallel to the nuclear envelope or located amongst cytoplasmic organelles '(Fig. 2).

\section{Synovial matrix}

This term is used to describe an intercellular substance of mesenchymal origin which provides a medium for embedment of synoviocytes. The matrix, as the other tissues of mesenchymal origin, consists of the amorphous and filamentous ground substances.

The structure of synovial matrix in the horse was different in different layers of the synovial membrane (Figs 1, 2, 4, 5). The surface consisted of a 2-3 $\mu \mathrm{m}$ layer composed of clusters of aperiodic, irregularly arranged fibrils and condensed amorphous material. This layer included cytoplasmic organelles and secretory granules in the forms of transport vacuoles or dense bodies (Figs 1, 2, 4,5). The aperiodic fibrils were observed only in the synovial membrane of equine knee joint. They presented as thick bundles either arranged in parallel to the membrane surface (Fig. 4) or located among synoviocytes (Fig. 2).

The synovial matrix enclosing cells (Figs $1,2,5$ ) formed a layer about $4-5 \mu \mathrm{m}$ thick. It was composed of typical collagen fibrils (periodicity, $64 \mathrm{~nm}$ ) arranged into bundles surrounding single cells; sectioning revealed the bundles cut both longitudinally and transversally. The collagen fibrils were attached to the cell membrane in both A- and Bsynoviocytes (Figs 1, 2, 5). In addition to collagen fibrils, some areas contained an accumulation of aperiodic fibril filling a lot of space.

Some differences were found in the arrangement of synovial matrix in regions where synoviocytes were located on the surface (Fig. 3). In the surface layer, the matrix was absent; it was observed in the deeper parts close to subsynovial tissue where it consisted of collagen fibrils arranged in various directions and secretory granules located at cell membranes. The basement membrane was not usually present where the surface layer consisted only of cells (Fig. 3).

\section{Discussion}

The synovial membrane, its structure and function has so far received considerable attention (reviewed by Ghadially 1983; Horký 1990,1991) and the studies in various mammalian species have been concerned with joint under physiological conditions as well as with those affected by disease (Gangel 1984; Hilbert et al. 1984; Worral et al. 1991). This abundance of information, however, has contained only few data related to the 
structure of synovial membrane in horses (Pe r s s o n 1971; J o h a n s on and Rejnö 1976; Horký 1993).

In describing the cells (synoviocytes) we followed the original classification of B a r l a n d et al. 1962). A characteristic feature of the synovial membrane in adult horses was, similarly to other mammals, a mixed population of differentiated type A and B cells. Their distribution corresponded to that reported for other mammalian species with the exception of rats (W a s sile v 1965). The structures of equine A- and B-cells were also in agreement with the findings made in the other mammals with one difference only: B-cells did not show in the cytoplasm the presence of secretory granules desribed by $\mathrm{Ok} \mathrm{a} \mathrm{da} \mathrm{et} \mathrm{al.}$ (1981) and Graabaek (1985). The cytoplasm of B-cells contained only occasional dense bodies, most probably lysosomes. These bodies were also observed in the synovial matrix close to the membrane surface and it is suggested that they are released into the articular cavity where they may, for instance, take part in the digestion of cartilage intercellular matter (Dingle 1984). In contrast to our earlier observations (Horký 1990, 1991) as well as the literature data, the synovial membrane in the horse did not have the transient A-B cell types. A further difference is the finding of intracytoplasmic filaments which are not present in the synovial membrane of cattle (Horký 1984) or pigs in early postnatal periods (Horký 1990). In both cell types, the basement membrane, absent in the pig (Horky 1990, 1991), was developed. In B-cells, we failed to detect the penetration of collagen fibrils through the cell membrane of $B$ cells.

The most unusual finding was the occurrence of big bundles of aperiodic filaments, $0.2-0.4 \mu \mathrm{m}$ thick and $5 \mu \mathrm{m}$ long, located in a depth of $1-2 \mu \mathrm{m}$ under the surface of synovial membrane. They were either arranged in parallel to the synovial surface or bent towards the deeper layer and finish their course among synoviocytes. As far as we are aware such filament bundles have never been observed in any mammalian synovial membrane and their origin is the subject of further studies. A comparison of the synovial membrane between knee and astragalar joints did not reveal any differences in its ultrastructure except for the presence of aperiodic fibrils in the synovial matrix of the knee joint.

\section{Submikroskopická struktura synoviální membrány koně}

Byla studována ultrastruktura synoviální membrány dospèlých koní. Vzorky byly odebrány ze dvou hlezenních a dvou kolenních kloubů hřebců anglického plemene a zpracovány pro účely transmisní elektronové mikroskopie obvyklým způsobem.

Bylo zjištěno, že podobně jako u jiných námi studovaných savců je i u koně synoviální membrána tvořena A a B buňkami a synoviální matrix, která přechází v subsynoviální tkáň. Synovialocyty jsou uloženy jednotlivě, zpravidla překryty vrstvou synoviální matrix, jen ojediněle jsou v kontaktu s kloubní dutinọu. A-buňky se neliší svou stavbou od tohoto typu buněk u jiných savců, jsou však značně oploštělé a postrádají cytoplasmatické výběžky. V cytoplasmě B-buněk nebyla prokázána sekretorická granula, ani průnik fibril přes buněčnou membránu. V synoviální matrix povrchové vrstvy byla pozorována četná tmavá tělíska. Neobvyklým nálezem byl výskyt mohutných svazků aperiodických filament dlouhých několik $\mu \mathrm{m}$, dosahujících tlouštky asi $0,2-0,3 \mu \mathrm{m}$.

\section{References}

BARLAND, P., NOVIKOFF, A. B., HAMERMAN, D. 1962: Electron microscopy of the human synovial membrane. J. Cell. Biol. 14: 207-220

CUTLIP, R. C., CHEVILLE, N. F. 1973: Structure of synovial membrane of sheep. Ann. J. Vet. Res. 34: 45-50 
DINGLE, J. T. 1984: The effect of synovial catabolin on cartilage synthetic activity. Conn. Tiss. Res. 12: 277-287

FABRY, G. 1989: Ultrastructural changes in synovium and cartilage in experimental hemarthrosis in dogs. Arch. Orthop. Traumat. Surg. 109/1: 21-29

GANGEL, H. 1984: Synovial fluid. In: Diseases of the horse. O. Dietz, W. Wiesner, S. Karger, AG, Basel.

GHADIALLY, F. N. 1983. Fine structure of synovial joint. Butterworths, London.

GRAABAEK, M. P.: 1985: Fine structure of the lysosomes in the two types of synoviocytes of normal rat synovial membrane. A cytochemical study. Cell Tissue Res. 239/2: 293-298

HILBERT, B. J., ROWLEY, G., ANTONAS, K. N. 1984: Hyaluronic acid concentration in synovial fluid from normal and arthritic joint of horses. Anat. Vet. J. 61: 22-24

HORKÝ, D. 1990. The ultrastructure of the porcine synovial membrane in the early postnatal development. Acta vet. Brno 59: 111-119

HORKÝ, D. 1991: Submicroscopic structure of synovial membrane in the adult pig. Acta vet. Brno 60: 3-13

HORKÝ, D. 1993: The ultrastructure of equine synovial membrane. Symposium cum partitipatione internationali, Brno, September 7-10, p. 43

JOHANSSON, H. E., REJNÖ, S. 1976: Light and electron microscopic investigation of equine synovial membrane. A comparison between healthy joint and joints with intraarticular fractures and osteochondrosis dissecans. Acta vet. Scand. 17: 153-168

LEACH, D. H., CALOWELL, S. J., FERGUSON, J. G. 1988: Ultrastructural study of synovial membrane from the antebrachiocarpal joint of calves. Acta Anat. 133: 234-246

LEVANON, D., STEIN, H. 1992: The synovial lining of the rabbit knee: A scanning electron microscopy study of specimens reinforced structurally with tannic acid. Histochem. J. 24: 25-32

MEEK, W. D., RABER, B. T., McCLAIN, O. M., McCOSH, J. K., BAKER, B. B. 1991: Fine structure of the human synovial lining cell in osteoarthritis: Its prominent cytoskeleton. Anat. Rec. 231: 145-155.

OKADA, Y., NAKANISHI, I., KAJIKAWA, K. 1981: Secretory granules of B-cells in the synovial membrane. An ultrastructural and cytochemical study. Cell Tiss. Res. 216: 131-141

PASQUALI-RONCHETTI, I., FRIZZIERO, L., GUERRA, D., BACCARANI-CONTRI M., FOCHERINI, M. C., GEOGOUNTZOS, A., VINCENZI, D., CICCHETTI, F., PERBELLINI, A., GOVONI, E. 1992: Aging of the human synovium: An in vivo and ex vivo morphological study. Semin. Arthritis Rheum. 21: 400-414

PERSSON, L. 1971: On the synovia in horses. Acta vet. scand. Suppl. 35

WASSILEW, W. 1975: Changes in the ultrastructure of the synovial membrane during growth and aging. Verh. Anat. Ges. 69: 427-431

WORRAL, J. G., BAYLISS, M. T., EDWARDS, J. C. W. 1991: Morphological localization of hyaluronan in normal and diseased synovium. J. Rheumatol. 18: 1 466-1 472. 
Plate XI.

Horký D., Tichý F.: The Ultrastructure... pp. 225-229.

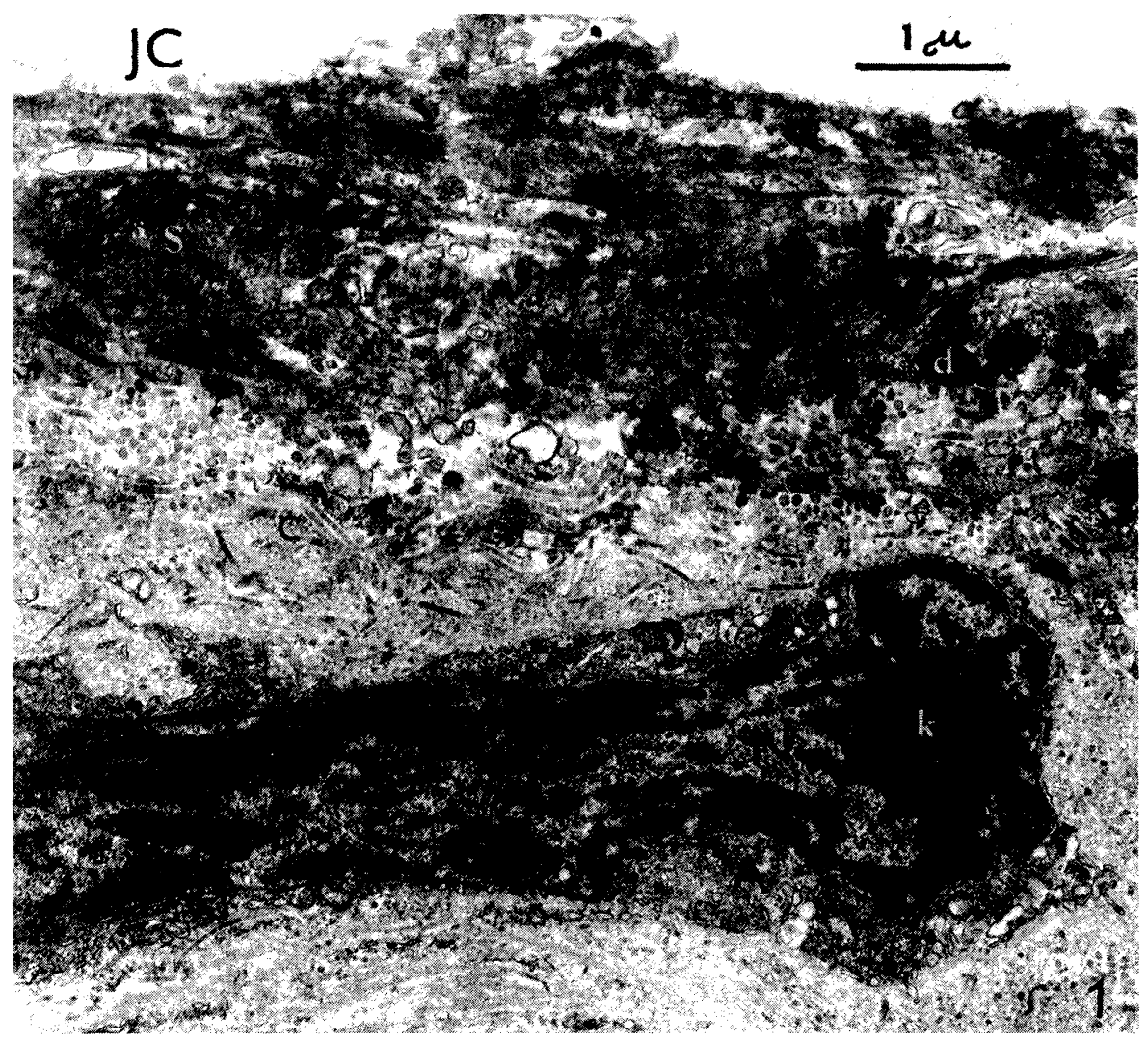

Fig. 1: Synovial membrane of the astragalar joint in the horse. Synoviocyte A (A) with the nucleus (N). Karyosomes (k), collagen fibrils (c), dense bodies (d) in the synovial matrix (S). Joint cavity (JC). x 17000.

Fig. 2: Synovial membrane of the knee joint in the horse. Synoviocyte B (B) with the nucleus (N) and karyosomes (k). Mitochondria (M), granular endoplasmic reticulum (G), transport vacuoles (t), dense bodies (d) in the synovial matrix (S). Collagen fibrils (c), basement membrane (bm). A bundle of aperiodic filaments (a) in the matrix. Joint cavity (JC). x 16000.

Fig. 3: B cell of synovial membrane of the astragalar joint (B) which is in contact with the joint cavity (JC). Nucleus $(\mathrm{N})$, karyosomes $(\mathrm{k})$, mitochondria $(\mathrm{M})$, cisternae of the granular endoplasmic reticulum (E), synovial matrix (S) with bundles of aperiodic filaments (a), collagen fibrils (c). X 17000. 
Plate XII.

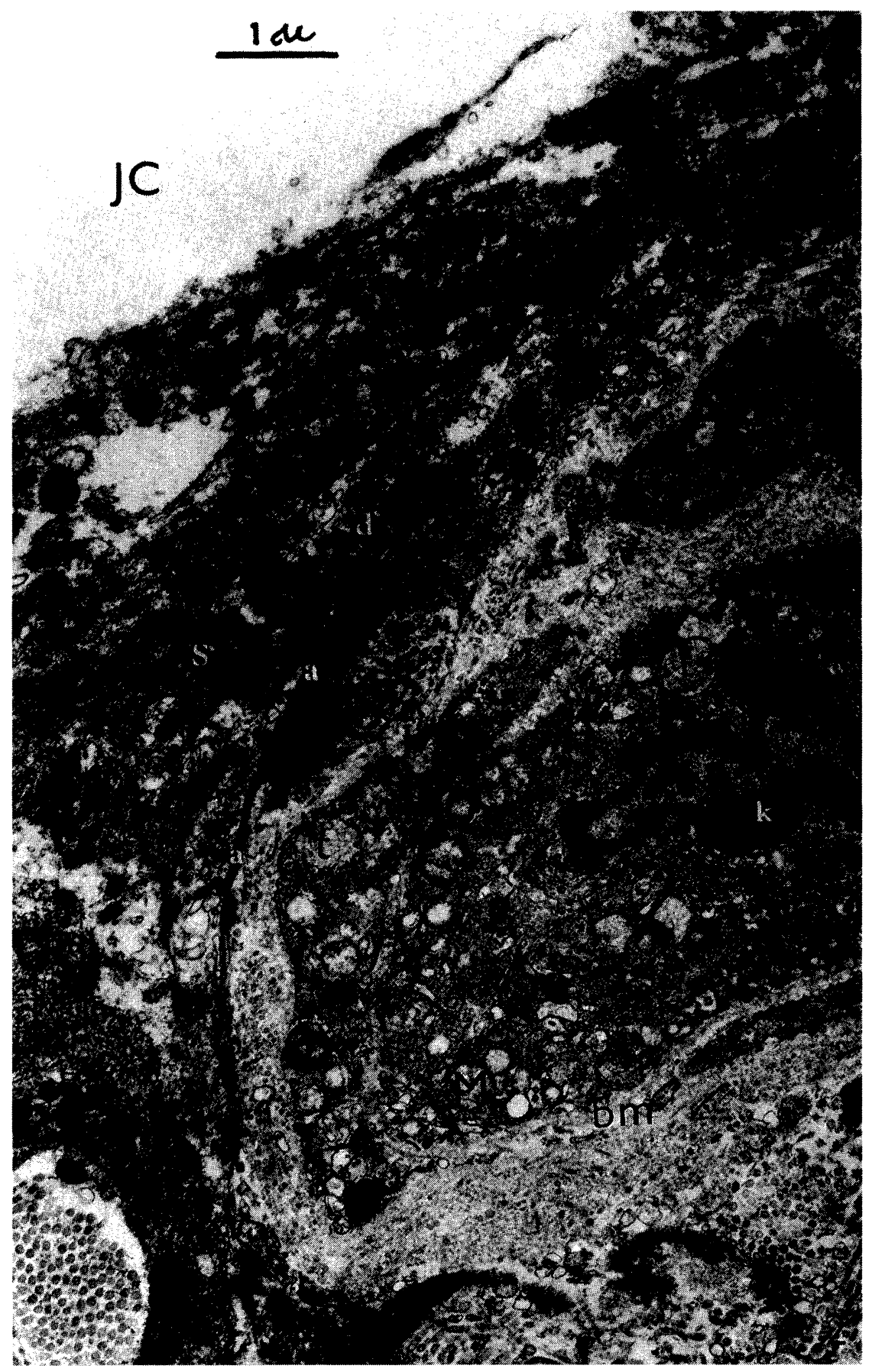




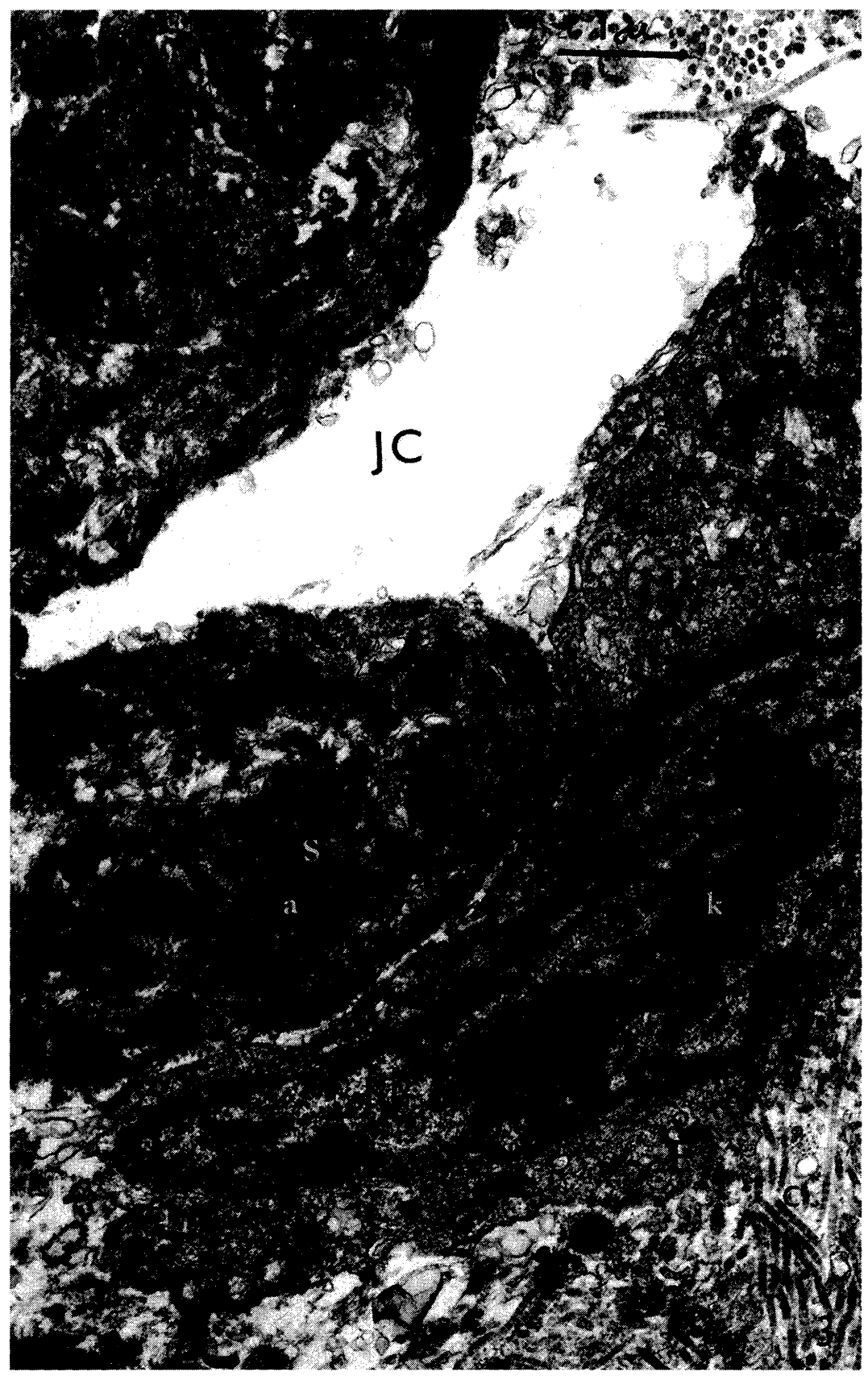




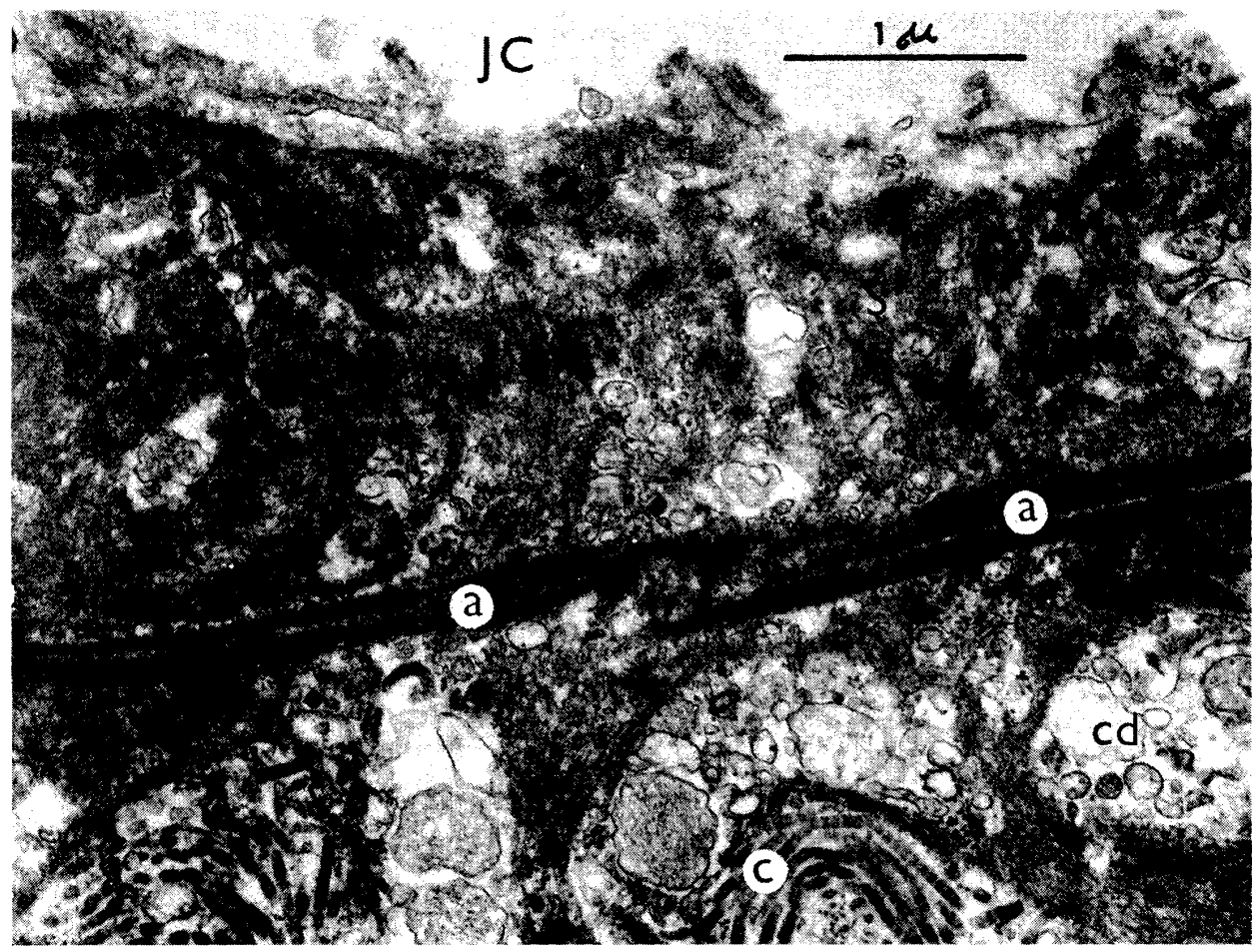

Fig. 4: Part of the surface layer of synovial matrix of the astragalar joint (S) which contains bundles of aperiodic filaments (a) and cellular detritus with remnants of cytoplasmic organelles (cd). Collagen fibrils (c), joint cavity (JC). x 30000 .

Fig. 5: Part of synovial membrane of the knee joint. Joint cavity (JC), synovial matrix (S) with dense bodies (d). Area of intercellular substance with collagen fibres (c) and aperiodic fibrils (a). Cell projections (cp), B cells (B) with the nuclei $(\mathrm{N})$, karyosomes $(\mathrm{k})$, granular endoplasmic reticulum (E), agranular endoplasmic reticulum (A), mitochondria (M). x 19000. 
Plate XV.

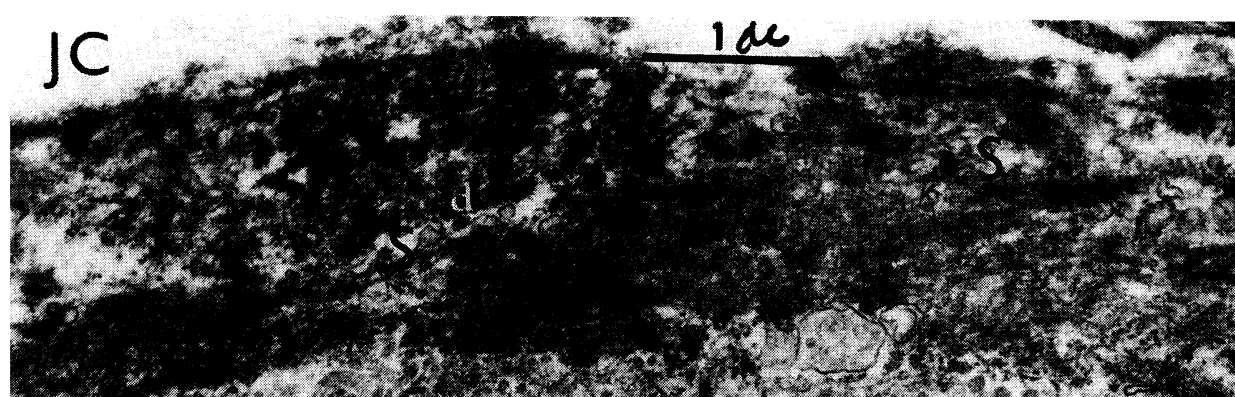

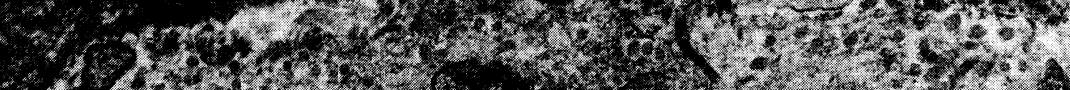

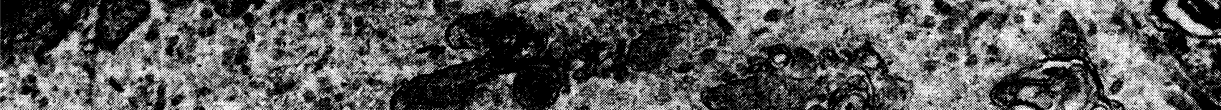

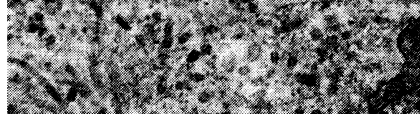

-

-

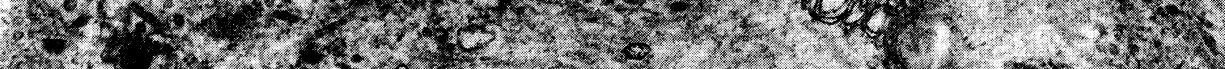
8.

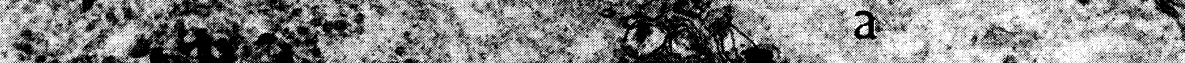

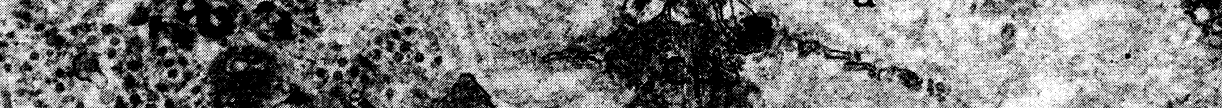

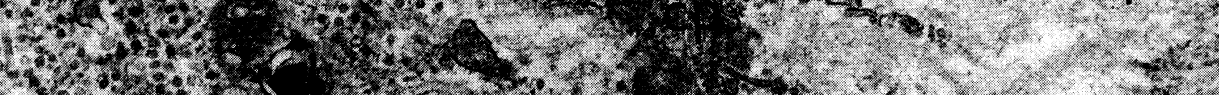

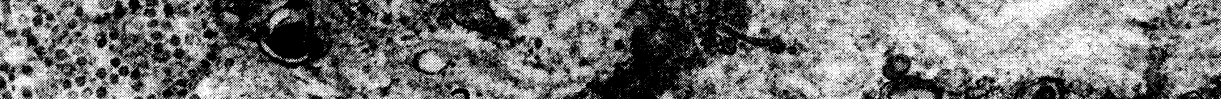
for.

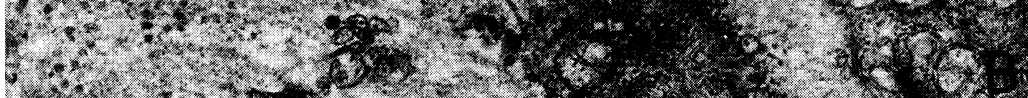

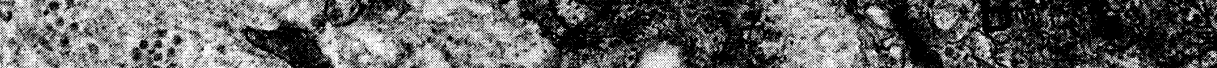

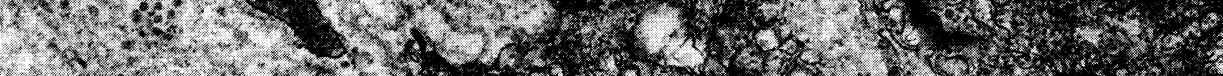
5.

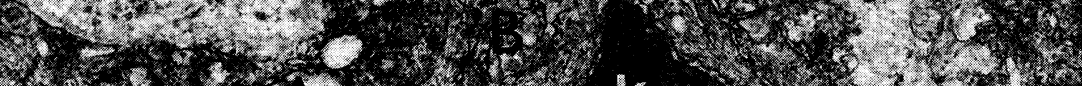

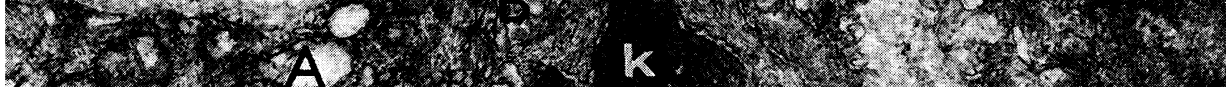
6.

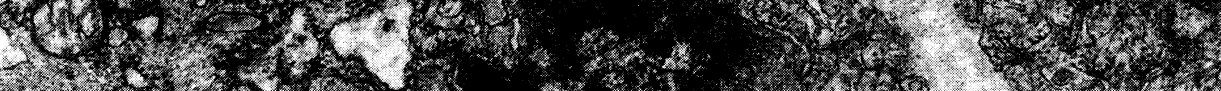

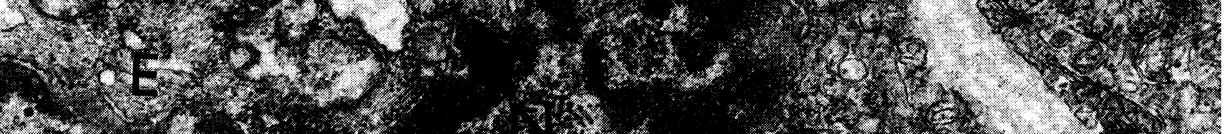

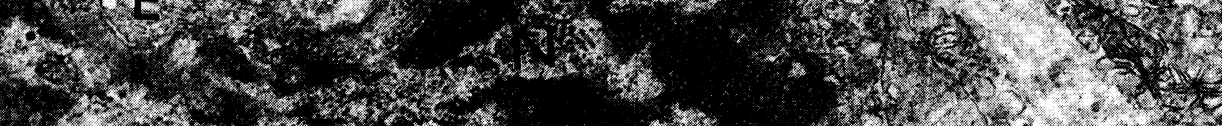

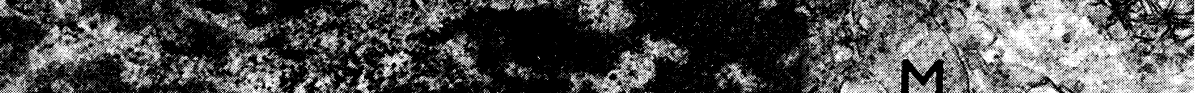

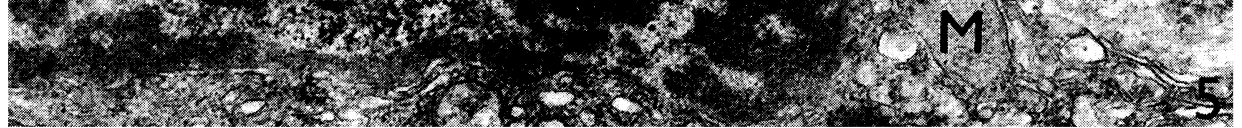

